\title{
Dimensional Accuracy Comparison of Physical Models Generated by Digital Impression/3D-Printing or Analog Impression/Plaster Methods
}

\author{
Comparación de Precisión Dimensional de Modelos Físicos Generados por \\ Métodos de Impresión Digital/Impresión 3D o Impresión Analógica/Yeso
}

\author{
Luciana Paula Benicio Arcas ${ }^{1}$; João Paulo Mendes Tribst'; Kusai Baroudi'; \\ Marina Amaral'; Lais Regiane da Silva-Concílio¹ \& Rafael Pino Vitti²
}

\begin{abstract}
ARCAS, L. P. B.; TRIBST, J. P. M.; BAROUDI, K.; AMARAL, M.; SILVA-CONCÍLIO, L. R. \& VITTI, R. P. Dimensional accuracy comparison of physical models generated by digital impression/3D-printing or analog impression/plaster methods. Int. J. Odontostomat., 15(3):562-568, 2021.

ABSTRACT: This study aimed to compare the trueness and precision of physical models manufactured chairside (intraoral scanner and 3D printed) or by plaster models obtained using impression with alginate or addition silicone. A fullarch stainless steel die was impressed to obtain ten physical models for each group. The models were measured in a stereomicroscope, considering four linear distances. To assess the precision accuracy, an analysis of the measurement variability was carried out, identified by the coefficients of variation and by the Levene's test to compare the groups. To analyze trueness, the data average was subtracted from the database and compared considering alpha as $5 \%$. Considering precision, the higher dispersion of data occurred in the models obtained with silicone impression. And for trueness, Kruskal Wallis and Dunn tests results did not indicate differences between the groups in the anteroposterior linear distances ( $p>$ $0.05)$. Only in anterior transverse distance obtained through TRIOS $(0.31 \mathrm{~mm})$, it presented lower accuracy compared to the models from silicone impression $(0.13 \mathrm{~mm})$; however, at transverse posterior distance, the models from silicone impression showed the lowest accuracy $(p<0.05)$. There was no difference between the models from scanning $(p>0.05)$. The physical dental models obtained by digital and analog workflows showed acceptable dimensional accuracy expressed by high precision and trueness. There is no difference between the evaluated intraoral scanner systems and the impression materials for the full-arch impression.
\end{abstract}

KEY WORDS: three-dimensional printing; dimensional measurement accuracy; data accuracy; dental models.

\section{INTRODUCTION}

Dental impression is one of the most essential and common procedure in dental practice (Patzelt et al., 2014; Gallardo et al., 2018; Carvalho et al., 2018; Adolfi et al., 2020). Different impression techniques are used to acquire a reliable model (Gallardo et al.) since inaccuracies can reduce the restorations quality (Patzelt et al.). Therefore, the dimensional accuracy is a primary requirement for impression materials, intraoral scanning or physical models made in plaster or 3D printer (Gallardo et al.; Carvalho et al.).
The major advantages of intraoral scanning are ease and simplicity of the procedure (Nayar \& Mahadevan, 2015; Wan et al., 2017), reduced chair time (Lee et al., 2018), more comfort for the patient in comparison to conventional impressions; and, a better communication between dental technicians and clinicians (Mangano et al., 2016). The accuracy of intraoral scanners is proven in the literature (Renne et al., 2017), however, it can vary according to the equipment, calibration and operator (Gjelvold et al., 2016).

\footnotetext{
1 School of Dentistry, University of Taubaté.Rua dos Operários 09, Centro, Taubaté, São Paulo, 12020-340, Brazil.

2 Department of dentistry, Herminio Ometto University Center, School of Dentistry. Av. Dr. Maximiliano Baruto, 500, Jardim Universitário, Araras - SP, 13607-339, Brazil.
} 
Three-dimensional virtual models are an acceptable alternative to conventional plaster models. However, there are still situations in which there is a need for physical models, such as: manufacturing of removable partial dentures, thermoplastic aligners and orthodontics (Nayar \& Mahadevan; Wan et al.).

The additive manufacturing technique was introduced in the medical field around 1920 and began to be used in Dentistry around 1980. It involves the obtaintion of impressions generated from 3D images or from a modelling software (Nayar \& Mahadevan; Wan et al.).

Despite the imminent digital workflow popularizing at present, in the field of prosthesis, addition silicone (polyvinyl siloxane) is the most popular material (Cervino et al., 2019) mainly for reliability (Carvalho et al.). In the field of orthodontics, alginate (irreversible hydrocolloid) is the most used impression material due to the cost and ease manipulation (Cervino et al.). However, information about the comparison of the plasters obtained with both materials and by $3 D$ printing is still scarce in the literature.

According to ISO 5725-1:2003 (2003) and ISO 5725-2:2003 (2003), the accuracy is determined by precision and fidelity. It was described that fidelity (trueness) is the ratio between the arithmetic mean of a number of test results and the accepted database value; while precision is the ratio between consecutive measurements results.
The aim of the present study was to evaluate the dimensional accuracy of physical models manufactured by four different processes: Printed models (Form2 - Formlabs, Somerville, USA) after scanning using two different scanners (TRIOS ${ }^{\circ}$ 3Shape, Copenhagen, Denmark; iTero $\AA$ - Align, San José, USA) and plaster models obtained with impressions in alginate (Hydrogum, Zhermack Spa, Badia Polesine, Rovigo, Italy) or addition silicone (Elite HD; Zhermack, Badia Palesine, Italy) (Fig. 1).

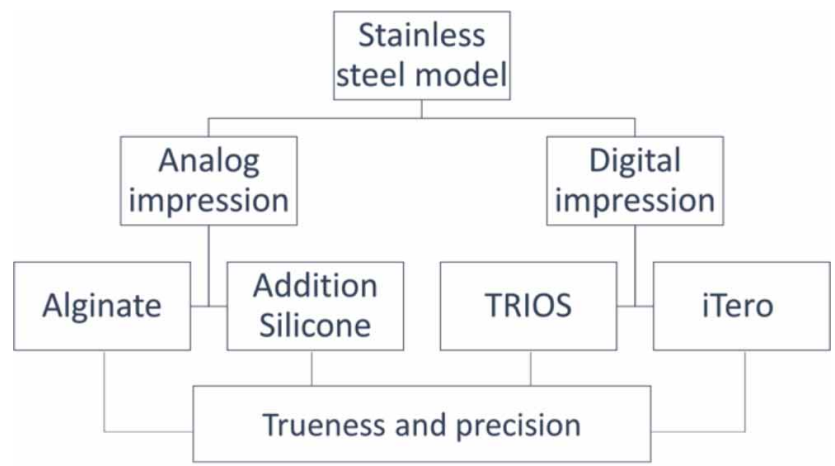

Fig. 1. Flowchart with the study design and evaluated impression methods.

\section{MATERIAL AND METHOD}

In this study, a stainless steel die representing a full-arch maxilla partially edentulous was used. The model had four reference points $\left(1 \mathrm{~mm}^{2}\right)$; so that the measurements could be performed with standardized references (Fig. 2A).
A

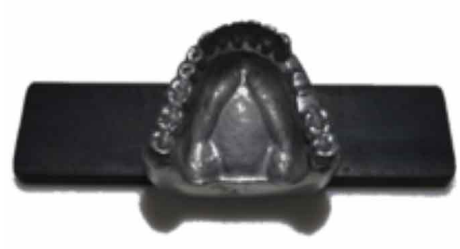

D

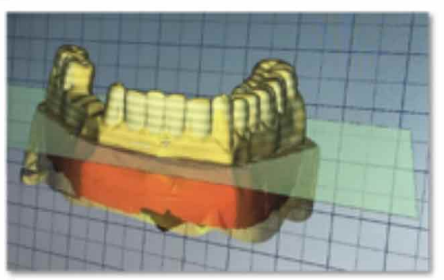

B

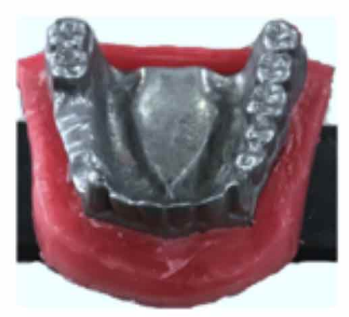

$\mathrm{E}$

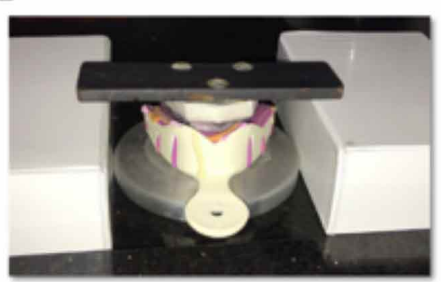

C

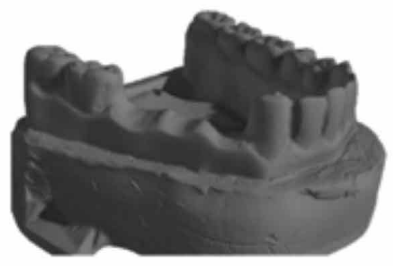

$\mathrm{F}$

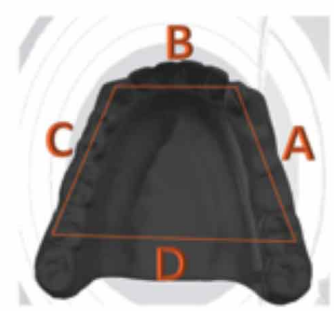

Fig. 2. A) Stainless Steel die dental model. B) Wax barrier prior to the impression. C) Stereolithographic models after digital impression. D) Virtual planning in the model base. E) Standardization of analog impression. F) Measured linear distances. 
A wax barrier was adapted around the master model (Fig. 2B) to allow a visible limit for the silicone and alginate impressions and to promote standardized plaster bases. During the impressions with silicone and alginate, similar volume of materials were used in the trays and an iron bar was attached to the base of the master model (Fig. 2E). This approach aimed to standardize the force applied to the tray, as well as, the distance between the model and the bottom of the tray.

The plaster models were made using special stone plaster (Fujirock EP Golden® - GC Corporation, Tokyo, Japan) and were stored at an average room temperature of 23. The same master model was scanned (Fig. 2C) and exported to the CAD software (Exocad GmbH, Darmstadt, Germany). After, the 3D file was modified removing the base (similar to the wax barrier position) before being printed (Fig. 2D). Finally, plaster and printed models were standardized with similar base height and dimensions.

Only one operator, following the scanning strategy and instructions given by the manufacturer of each product, performed the digital impressions. The scanning process time were recorded. Both the construction of the 3D image and the conversion to STL file format were carried outby the scanner's own software. The files in STL format were properly identified, exported to the CAD software (Exocad $\mathrm{GmbH}$, Darmstadt, Germany) and printed using the inoffice 3D printer (Form2, Formslab, Somerville, MA). Five models were printed at a time.
After 48 hours of the models manufacturing, plaster models and printed models were submitted to the measurements using a stereomicroscope (Olympus Measuring Microscope STM, Olympus Optical Co., Japan) with 30X magnification. Two anteroposterior linear distances (A- right and $\mathrm{C}$ - left) and two transverse (B- anterior and D- posterior) were obtained (Fig. 2F) by a single trained operator.

\section{RESULTS}

The descriptive statistics results $(\mathrm{mm})$ with average, standard deviation, variance, coefficient of variation, maximum and minimum values (with four linear measured distances) are summarized in Table I.

Levene's test compared of variances (Table II) identified significant differences between the groups. The variance was greater in the models obtained from silicone, in measurements $\mathrm{B}, \mathrm{C}$ and $\mathrm{D}$.

In Table III, regarding the models' fidelity, the values $(\mathrm{mm})$ resulting from the subtraction between the models averages and the real measurements from the master model were used.

Due to the non-normality and the heteroscedasticity of the data, non-parametric statistics were chosen. Thus, in terms of fidelity, the results of Kruskal Wallis and Dunn tests did not indicate

Table I. Average (mm), standard deviation, variance, coefficient of variation, maximum and minimum values, in four linear distances measured for each group.

\begin{tabular}{lccccccc}
\hline Group-region & Average & $\begin{array}{c}\text { Std. } \\
\text { Dev. }\end{array}$ & Variance & $\begin{array}{c}\text { Coefficient of } \\
\text { variation }\end{array}$ & Minimum & Median & Maximum \\
\hline TS-A & 34.96 & 0.12 & 0.014 & 0.35 & 34.75 & 34.94 & 35.13 \\
TS-B & 25.16 & 0.09 & 0.009 & 0.39 & 24.98 & 25.17 & 25.28 \\
TS-C & 35.18 & 0.13 & 0.018 & 0.38 & 35.00 & 35.19 & 35.47 \\
TS-D & 50.32 & 0.17 & 0.029 & 0.34 & 50.02 & 50.37 & 50.49 \\
IS-A & 34.78 & 0.12 & 0.016 & 0.36 & 34.56 & 34.78 & 34.98 \\
IS-B & 25.02 & 0.069 & 0.004 & 0.28 & 24.89 & 25.03 & 25.11 \\
IS-C & 35.02 & 0.085 & 0.007 & 0.24 & 34.84 & 35.05 & 35.14 \\
IS-D & 50.03 & 0.15 & 0.024 & 0.31 & 49.78 & 50.04 & 50.24 \\
SILI-A & 34.80 & 0.081 & 0.006 & 0.23 & 34.60 & 34.80 & 34.89 \\
SILI-B & 25.02 & 0.027 & 0.007 & 0.11 & 24.97 & 25.03 & 25.06 \\
SILI-C & 35.12 & 0.032 & 0.001 & 0.11 & 35.06 & 35.12 & 35.18 \\
SILI-D & 49.95 & 0.11 & 0.013 & 0.23 & 49.66 & 49.98 & 50.08 \\
ALG-A & 34.93 & 0.13 & 0.017 & 0.38 & 34.59 & 34.94 & 35.06 \\
ALG-B & 25.01 & 0.16 & 0.028 & 0.67 & 24.79 & 25.00 & 25.30 \\
ALG-C & 35.08 & 0.25 & 0.065 & 0.73 & 34.82 & 35.03 & 35.63 \\
ALG-D & 49.13 & 0.42 & 0.178 & 0.86 & 48.49 & 49.20 & 49.70 \\
\hline
\end{tabular}


differences between groups in $A$ and $C(p>0.05)$; only in $\mathrm{B}$. The model obtained by TRIOS (median $=0.31$ ) was less accurate than the model obtained by silicone
( median $=0.13$ ); but at distance $\mathrm{D}$, the models obtained from silicone showed less accuracy than the others groups $(\mathrm{p}<0.05)$.

Table II. Levene's test results to compare the variances considered $95 \%$ confidence interval.

\begin{tabular}{|c|c|c|c|c|c|c|}
\hline $\begin{array}{l}\text { Linear } \\
\text { distances }\end{array}$ & $\begin{array}{l}\text { Impression } \\
\text { method. }\end{array}$ & Min. (mm) & Std. Dev (mm) & Max. (mm) & $\begin{array}{c}\text { Test } \\
\text { value }\end{array}$ & p-value \\
\hline \multirow{5}{*}{$A$} & TRIOS & 0.07 & 0.12 & 0.26 & 0.66 & 0.580 \\
\hline & iTERO & 0.07 & 0.12 & 0.27 & & \\
\hline & Silicone & 0.08 & 0.13 & 0.29 & & \\
\hline & Alginate & 0.05 & 0.08 & 0.17 & & \\
\hline & TRIOS & 0.06 & 0.09 & 0.21 & 4.86 & 0.006 \\
\hline \multirow{3}{*}{$B$} & iTERO & 0.04 & 0.06 & 0.15 & & \\
\hline & Silicone & 0.10 & 0.16 & 0.36 & & \\
\hline & Alginate & 0.01 & 0.02 & 0.05 & & \\
\hline \multirow{4}{*}{ C } & TRIOS & 0.08 & 0.13 & 0.02 & 4.52 & 0.009 \\
\hline & iTERO & 0.05 & 0.08 & 0.18 & & \\
\hline & Silicone & 0.15 & 0.25 & 0.56 & & \\
\hline & Alginate & 0.02 & 0.03 & 0.08 & & \\
\hline \multirow{4}{*}{$D$} & TRIOS & 0.10 & 0.17 & 0.38 & 4.79 & 0.007 \\
\hline & iTERO & 0.09 & 0.15 & 0.34 & & \\
\hline & Silicone & 0.26 & 0.42 & 0.93 & & \\
\hline & Alginate & 0.07 & 0.11 & 0.25 & & \\
\hline
\end{tabular}

Table III. Comparison of model discrepancies $(\mathrm{mm})$ using the Kruskal Wallis and Dunn tests.

\begin{tabular}{ccccc}
\hline $\begin{array}{c}\text { Linear } \\
\text { distances }\end{array}$ & Trios & iTero & Silicone & Alginate \\
\hline A & $0.10^{\mathrm{a}}$ & $0.09^{\mathrm{a}}$ & $0.11^{\mathrm{a}}$ & $0.05^{\mathrm{a}}$ \\
B & $0.31^{\mathrm{a}}$ & $0.16^{\mathrm{ab}}$ & $0.13^{\mathrm{b}}$ & $0.16^{\mathrm{ab}}$ \\
C & $0.15^{\mathrm{a}}$ & $0.04^{\mathrm{a}}$ & $0.14^{\mathrm{a}}$ & $0.08^{\mathrm{a}}$ \\
D & $0.29^{\mathrm{D}}$ & $0.15^{\mathrm{b}}$ & $0.88^{\mathrm{a}}$ & $0.11^{\mathrm{b}}$ \\
\hline
\end{tabular}

\section{DISCUSSION}

The present study aimed to compare trueness and precision of physical models manufactured chairside (intraoral scanner and 3D printed) or plaster models obtained using impression with alginate or silicone. The results showed that there was no difference between the models obtained from scanning ( $p>0.05$ ). However, in B and D distance the factors were significant. Therefore, the null hypothesis has been partially denied.

According to previous studies (Gjelvold et al.; Mangano et al., 2020) with similar methodology, the major difficulty when measuring linear distances digitally or in physical models is the reference points to be used for such measurements. In the present study, the master model was manufactured with pinheads as reference points. Since the model was made in metal instead of resin, there was no distortion over time. In addition, ISO 4823:2000 (2000) recommends the use of metallic dies to perform the linear measurements in dental models. Another advantage of the present methodology is the effective standardization of the force applied without the need for plaster cutters in the process; therefore, reducing the defects population and possible processing errors during the models manufacturing.

In the intragroup analysis of the measurements obtained in each segment, the standard deviation was low in all groups. It demonstrates that regardless the method, there is precision in the reproducibility of the models. It is noted, however, that the coefficient of variation was lower in all linear distances in the alginate group ( $<30 \%)$, and higher in the silicone group, indicating a very high dispersion of data (>30\%). To test the significance of the difference between the groups variance, Levene's test was used. The test proved that the dispersion in the silicone group was significantly higher than the other groups $(p<0.05)$.

A previous study evaluated the effect of storage time on the dimensional stability of conventional and extended-pour alginates (Rohanian et al., 2014). The authors compared different brands and found that Hydrogun presented the best method for precise 
reproduction of dental tissues. Therefore, the ease impression and the quality of the tested alginate, contributed to the present results.

One of the most important properties for impression materials is the dimensional stability which affects the accuracy of the impressions and the casts. Generally, the linear dimensional change of alginate impression materials shall not exceed $1.0 \%$ (Vrbova et al., 2020). In addition, the alginate impression materials compared to elastomeric materials, are more sensitive to the disinfectant agents (Vrbova et al., 2020). They can be affected by certain types of disinfectants resulting in subsequently negative effects on the dimensional stability (Vrbova et al.). However, in the present study, this factor has not been simulated since it was an in vitro test with the stainless steel die as baseline.

Similar to the present study, another report evaluated the accuracy of digital impressions obtained through different scanning modalities in comparison with standard plaster model (Labib et al., 2020). The authors found that the digitization of dentition produced an accurate replica of the dentition compared to the gold standard analog method (Labib et al.). The present study corroborates with this statement.

Comparing different elastomeric materials, a previous study (Lotfy \& Thabet, 2018) aimed to compare the dimensional stability of extended-pour alginates and polyether impression materials. The authors found that the extended pour alginates achieved clinically acceptable range of dimensional accuracy. Corroborating with that, the present study demonstrates no difference between addition silicone and the extended-pour alginate material. Therefore, both can be indicated and the dentist can choose the material that is more convenient for each treatment. However, the literature reports that the alginate material are popular because of their low cost and ease of use compared to other impression materials (Nassar et al., 2011); what is positive for the patient's dental treatment accessibility and oral health maintenance (Joda \& Brägger, 2015).

Still regarding the treatment accessibility, for unitary restorations, the direct treatment costs were significantly lower for the digital workflow compared to the conventional modality with an overall cost minimization of $18 \%$ within the digital process (Joda \& Brägger). In this sense, the present study suggests that the use of digital workflow with intraoral scanners and 3D printed models can be a valid option to the analog methods of impressions.
Comparing conventional and digital impressions techniques, previous authors (Viegas et al., 2020) found that there are no statistical significant difference between these impression techniques for partial maxillary arch, and that the effect size is low for both trueness and precision. The present study corroborates with this statement and complement this information suggesting that the same behavior can be noted for full-arch impressions. However, it is important to note that intraoral scanning has its own challenges, such as: presence of saliva, soft tissue movement presented by the tongue, coupled with the presence of metallic reflective restorations making intra-oral surfaces difficult to capture (Labib et al.).

A previous study (Diker \& Tak, 2020) evaluated six different intraoral scanning systems and found that there was no statistical significant difference between TRIOS and iTero, the same scanners evaluated in the present study. However, different from the present study, the authors performed $3 \mathrm{D}$ models superimpositions to obtain trueness and precision values.

A case report, performed conventional impression (double-cord retraction and vinyl polysiloxane material), and digital impression with three different intraoral scanners (TRIOS $\otimes$, True Definition $®$ and iTero $®$ ) in the same patient. The authors did not report differece between techniques and suggested that conventional or digital impressions are able to produce adequate final dental-supported restorations (García-Gil et al., 2020). The present results corroborate with that; however, for full-arch impression, the alginate impression seems to be a more suitable material instead addition silicone.

Another study (Nassar et al.), compared the trueness of 12 different intraoral scanning systems, including TRIOS and iTero groups. The authors found that the iTero was superior in terms of accuracy in comparison with TRIOS to dental implant impression. The authors performed linear measurements similar to the present study and reported that the linear measurements are reliable, however, it is necessary to work on specific landmarks. In agreement with that, the present die model received pinheads as references during the experimental design.

The superior accuracy of iTero in comparison with TRIOS was also reported in a previous study that evaluated three intraoral scanners for the impression of a complete dental arch (Iturrate et al., 2019). Similar to the present results, digital impressions were less precise as the scanning length of the arch increased. 
In this study, regardless the physical model manufacturing, some kind of error were presented. In the conventional workflow, the impression materials can shrink, expand, or warp during or after removal from the mouth, resulting in inaccuracies (Iturrate et al.). In addition, at the same time, it is important to note that the impressions obtained with the intraoral scanning systems followed a digital workflow with 3D printing physical model for the microscopy measurement. In this sense, for the additive manufacturing, parameters such layer thickness, base design, post processing and storage, can significantly affect the model's accuracy and modify the results (Etemad-Shahidi et al., 2020; Arcila et al., 2020).

According to the literature, ambient lighting conditions can modify the accuracy (trueness and precision) of the intraoral scanner systems. For TRIOSTRIOS, a proper room light can result in a better accuracy. However, for iTero, both chair and room light conditions are necessary to achieve a more accurate impression (Revilla-León et al., 2020a).

The mesh quality also can be affected by the different intra-oral scanners. The photographic scanning techniques present higher mesh quality mean values than the tested video-based scanning technology. Moreover, TRIOS can present the highest consistency in terms of the mean mesh quality, indicating better photographic system in comparison with iTero (Revilla-León et al., 202 b).

There was a significant difference in fidelity in relation to the master model and the models printed from scanning with the TRIOS $₫$ scanner in the transverse anterior distance (B); and, in the plaster models obtained using silicone in the transverse posterior distance (D). According to literature (Carvalho et al.), silicone impressions are subject to change due to, per example, the type of tray used and pressure to remove the impression; which demonstrates that despite it is an excellent material, conventional silicone impression was the most sensitive impression technique, according to results obtained in the present study.

The limitations of the present study are that the scanners were used with in vitro specimens, without considering the patient soft tissue, mouth opening limitations, saliva and different incidences of light. The alginate and silicone impressions were perfectly inserted, without saliva or patient's discomfort. Therefore, the results presented herein should be carefully extrapolated and the data available in literature must be used as a complement prior to any clinical decision based on it.

\section{CONCLUSION}

The physical dental models obtained with digital and analog workflows showed acceptable dimensional accuracy expressed by high precision and trueness. There is no difference between the evaluated intraoral scanner systems and impression materials for the fullarch impression.

ARCAS, L. P. B.; TRIBST, J. P. M.; BAROUDI, K.; AMARAL, M.; SILVA-CONCÍLIO, L. R. \& VITTI, R. P. Comparación de precisión dimensional de modelos físicos generados por métodos de impresión digital/impresión 3D o impresión analógica/yeso. Int. J. Odontostomat., 15(3):562-568, 2021

RESUMEN: Este estudio tuvo como objetivo comparar la veracidad y precisión de modelos físicos fabricados en la clínica dental (escáner intraoral e impreso en 3D) o por modelos de yeso obtenidos mediante impresión con alginato o silicona de adición. Una matriz de acero inoxidable de arco completo fue impresa para obtener diez modelos físicos para cada grupo. Los modelos se midieron en un estereomicroscopio, considerando cuatro distancias lineales. Se realizó un análisis de la variabilidad de la medida para evaluar la precisión, identificada por los coeficientes de variación y por la prueba de Levene para comparar los grupos. Para analizar la veracidad, el promedio de los datos se restó de la base de datos y se comparó considerando alfa como $5 \%$. Considerando la precisión, la mayor dispersión de datos ocurrió en los modelos obtenidos con impresión de silicona. Y para la veracidad, los resultados de las pruebas de Kruskal Wallis y Dunn no indicaron diferencias entre los grupos en las distancias lineales anteroposteriores $(p>0,05)$. Solo en la distancia transversal anterior obtenida mediante TRIOS $(0,31 \mathrm{~mm})$ presentó menor precisión en comparación con los modelos de impresión de silicona $(0,13 \mathrm{~mm})$; sin embargo, la distancia transversal posterior, los modelos de impresión de silicona mostraron la menor precisión $(p<0,05)$. No hubo diferencia entre los modelos de escaneo $(p>0,05)$. Los modelos dentales físicos obtenidos mediante flujos de trabajo digitales y analógicos mostraron una precisión dimensional aceptable expresada por alta precisión y veracidad. No se observó diferencia entre los sistemas de escáner intraoral evaluados y los materiales de impresión para la impresión de arco completa.

PALABRAS CLAVE: impresión tridimensional; precisión de medición dimensional; precisión de los datos; modelos dentales. 
ARCAS, L. P. B.; TRIBST, J. P. M.; BAROUDI, K.; AMARAL, M.; SILVA-CONCíLIO, L. R. \& VITTI, R. P. Dimensional accuracy comparison of physical models generated by digital impression/3D-printing or analog impression/plaster methods. Int. J. Odontostomat., 15(3):562-568, 2021.

\section{REFERENCES}

Adolfi, D.; Tribst, J. P. M.; Adolfi, M.; Dal Piva, A. M. O.; Saavedra, G. S. F. A. \& Bottino, M. A. Lithium disilicate crown; zirconia hybrid abutment and platform switching to improve the esthetics in anterior region: a case report. Clin. Cosmet. Investig. Dent.,12:31-40, 2020.

Arcila, L. V. C.; de Carvalho Ramos, N.; Bottino, M. A. \&Tribst, J. P. M. Indications; materials and properties of 3D printing in dentistry: a literature overview. Res. Soc. Dev., 9(11):e80791110632, 2020.

Carvalho, T. F.; Lima, J. F. M.; De Matos, J. D. M.; Lopes, G. D. R.; De Vasconcelos, J. E. L.; Zogheib, L. V. \& De Castro, D. S. M. Evaluation of the accuracy of conventional and digital methods of obtaining dental Impressions. Int. J. Odontostomat., 12(4):368-75, 2018.

Cervino, G.; Fiorillo, L.; Herford, A. S.; Laino, L.; Troiano, G.; Amoroso, G.; Crimi, S.; Matarese, M.; D’Amico, C.; Siniscalchi, E. N.; et al. Alginate materials and dental impression technique: A current state of the art and application to dental practice. Mar. Drugs, 17:1-15, 2019.

Diker, B. \& Tak, Ö. Comparing the accuracy of six intraoral scanners on prepared teeth and effect of scanning sequence. J. Adv. Prosthodont., 12(5):299-306, 2020.

Etemad-Shahidi, Y.; Qallandar, O. B.; Evenden, J.; Alifui-Segbaya, F. \& Ahmed, K. E. Accuracy of 3-Dimensionally Printed Full-Arch Dental Models: A Systematic Review. J. Clin. Med., 9(10):3357, 2020.

Gallardo, Y. R.; Bohner, L.; Tortamano, P.; Pigozzo, M. N.; Laganá, D. C. \& Sesma, N. Patient outcomes and procedure working time for digital versus conventional impressions: A systematic review. J. Prosthet. Dent.,119(2):214-9, 2018.

García-Gil, I.; Perez de la Calle, C.; Lopez-Suarez, C.; Pontevedra, P. \& Suarez, M. J. Comparative analysis of trueness between conventional and digital impression in dental-supported fixed dental prosthesis with vertical preparation. J. Clin. Exp. Dent., 12(9):e896-e901, 2020

Gjelvold, B.; Ramos Chrcanovic, B.; Korduner, E- K.; Collin-Bagewitz, I. \& Kisch, J. Intraoral digital impression technique compared to conventional impression technique. A randomized clinical trial. J. Prosthodont., 25:282-7, 2016.

ISO 4823:2000. Dentistry-Elastomeric Impression Materials. Geneva, International Organization for Standardization, 2000.

ISO 5725-1:2003. Accuracy (Trueness and Precision) of Measurement Methods and Results-Part 1: General Principles and Definitions. Geneva, International Organization for Standardization, 2003.

ISO 5725-2:2003. Accuracy (Trueness and Precision) of Measurement Methods and Results-Part 2: Basic Method for the Determination of Repeatability and Reproducibility of a Standard Measurement Method. Geneva, International Organization for Standardization, 2003.

Iturrate, M.; Lizundia, E.; Amezua, X. \& Solaberrieta, E. A new method to measure the accuracy of intraoral scanners along the complete dental arch: A pilot study. J. Adv. Prosthodont., 11(6):331-40, 2019.

Joda, T. \& Brägger, U. Digital vs. conventional implant prosthetic workflows: a cost/time analysis. Clin. Oral Implants Res., 26(12):1430-5, 2015.

Labib, M. A.; El-Beialy, A. R. \& Attia, K. H. Evaluation of the accuracy of digital models obtained using intraoral and extraoral scanners versus gold standard plaster model (diagnostic accuracy study). Open J. Med. Imaging, 10(3):151, 2020.

Lee, H.; Cha, J.; Chun, Y. S. \& Kim, M. Comparison of the occlusal contact area of virtual models and actual models: a comparative in vitro study on Class I and Class II malocclusion models. BMC Oral Health, 18(1):109, 2018.

Lotfy, S. \& Thabet, Y. G. Effect of two different impression materials on the accuracy of the master casts of partially edentulous cases (invitro study). Egypt. Dent. J., 64(4):3935-41, 2018.
Mangano, F. G.; Admakin, O.; Bonacina, M.; Lerner, H.; Rutkunas, V. \& Mangano, C. Trueness of 12 intraoral scanners in the full-arch implant impression: a comparative in vitro study. BMC Oral Health, 20(1):263, 2020.

Mangano, F. G.; Veronesi, G.; Hauschild, U.; Mijiritsky, E. \& Mangano, C. Trueness and precision of four intraoral scanners in oral implantology: a comparative in vitro study. PLoS One,11(9): e0163107, 2016

Nassar, U.; Aziz, T. \& Flores-Mir, C. Dimensional stability of irreversible hydrocolloid impression materials as a function of pouring time: a systematic review. J. Prosthet. Dent., 106(2):126-33, 2011.

Nayar, S. \& Mahadevan, R. A paradigm shift in the concept for making dental impressions. J. Pharm. Bioallied. Sci., 7(Suppl. 1):S213-5, 2015.

Patzelt, S. B. M.; Bishti, S.; Stampf, S. \& Att, W. Accuracy of computeraided design/computer-aided manufacturing-generated dental casts based on intraoral scanner data. J. Am. Dent. Assoc., 145(11):113340, 2014.

Renne, W.; Ludlow, M.; Fryml, J.; Schurch, Z.; Mennito, A.; Kessler, R. \& Lauer, A. Evaluation of the accuracy of 7 digital scanners: An in vitro analysis based on 3-dimensional comparisons. J. Prosthet. Dent., 118(1):36-42, 2017.

Revilla-León, M.; Jiang, P.; Sadeghpour, M.; Piedra-Cascón, W.; Zandinejad, A.; Özcan, M. \& Krishnamurthy, V. R. Intraoral digital scans-part 1: influence of ambient scanning light conditions on the accuracy (trueness and precision) of different intraoral scanners. J. Prosthet. Dent., 124(3):372-8, 2020a.

Revilla-León, M.; Jiang, P.; Sadeghpour, M.; Piedra-Cascón, W.; Zandinejad, A.; Özcan, M. \& Krishnamurthy, V. R. Intraoral digital scans: Part 2-influence of ambient scanning light conditions on the mesh quality of different intraoral scanners. J. Prosthet. Dent., 124(5):575-80, 2020b.

Rohanian, A.; Ommati Shabestari, G.; Zeighami, S.; Samadi, M. J. \& Shamshiri, A. R. Effect of storage time of extended-pour and conventional alginate impressions on dimensional accuracy of casts. J. Dent. (Tehran), 11(6):655-64, 2014.

Viegas, D. C.; Mourão, J. T.; Roque, J. C.; Riquieri, H.; Fernandes, J.; Arrobas, F. V.; Diamantino, P. J. S. \& Saavedra, G. S. A. Evaluation of the influence of the impression technique; scanning direction and type of scanner on the accuracy of the final model. Braz. Dent. Sci., 24(1):1-13, 2020.

Vrbova, R.; Bradna, P.; Bartos, M. \& Roubickova, A. The effect of disinfectants on the accuracy; quality and surface structure of impression materials and gypsum casts: A comparative study using light microscopy; scanning electron microscopy and micro computed tomography. Dent. Mater. J., 39(3):500-8, 2020.

Wan Hassan, W. N.; Yusoff, Y. \& Mardi, N. A. Comparison of reconstructed rapid prototyping models produced by 3-dimensional printing and conventional stone models with different degrees of crowding. Am. J. Orthod. Dentofac. Orthop., 151(1):209-18, 2017.

Corresponding author:

João Paulo Mendes Tribst

D.D.S.; M.D.; Ph.D.

Professor Postgraduate program

Department of Dentistry - School of Dentistry

University of Taubaté (UNITAU)

Rua dos Operários 09, Centro

Taubaté -São Paulo 12020-340

BRAZIL

E-mail: joao.tribst@gmail.com

ORCID: https://orcid.org/0000-0002-5412-3546 